\title{
Richard Schechner ve Bir Eşiksellik Paradigması: Performans
}

\author{
Richard Schechner and A Paradigm of Liminality: Performance \\ İbrahim Güngör
}

\begin{abstract}
Özet
Bu çalışma Richard Schechner'in 1970 sonrası antropoloji ile kurduğu yakınlaşmayla beraber üzerinde detaylı olarak durmaya başladığı ve yeni bir paradigma olarak ifade ettiği 'performans' düşüncesinin bir anatomisini çıkarmayı hedeflemektedir. Bunu yaparken de Schechner'in bir dönem birlikte çalıștı̆̆ antropolog Victor Turner'dan devralarak kullandığı 'eşik', aradalık (liminal) kavramı çerçevesinde bir anlatı kurulmaya çalışılmıștır. Schechner'in genelde sosyal bilimler özelde antropoloji ile kurduğu yakınlık, performans algısını değiștirdiği gibi ritüel-tiyatro ilişskisine, kültür, oyun gibi kavramlara yeni bakış açıları getirmesini de sağlamıştır. Schechner 1950'lerin sonunda Amerika'nın hareketli toplumsal ikliminde başladığı tiyatro çalışmalarını 1980 sonrası büyük ölçüde performans araştırmaları merkezine kaydırmış, tiyatro-antropoloji ilişkisini farklı açılardan ele almış ve 'performans'ı tiyatro çerçevesinde değil tiyatroyu 'performans' çerçevesinde okumuştur. Schechner'in kapsayıcı bir paradigma olarak ele aldığı performans doğa-kültür, sanat-hayat korelasyonlarının yeni perspektiflerle okunmasını sağlamaktadır. Temel olarak Schechner düşüncesi kendisini batıll, Avrupa-Amerika merkezli egemen kültürün ve onun sınırlama, sınıflama anlayışının karşısında, eşikselliklere değer veren bir alanda, 'kesişimler, etkileșimler, belirsizlikler' alanında konumlandırmaktadır.
\end{abstract}

Anahtar Sözcükler: Performans, antropoloji, tiyatro, kültür, oyun, eşik.

Akademik disipin(ler)/alan(lar): Performans, tiyatro, antropoloji.

\begin{abstract}
This study aims to map out the anatomy of the idea of 'performance' which Richard Schechner begins to dwell upon in detail following the 1970s with the linking he makes to anthropology and which he puts forward as a new paradigm. In doing so it utilises the concept of the liminal, borrowed by Schechner from Victor Turner, an anthropologist he spent time working together with. The connection Schechner draws with the social sciences in general and anthropology in particular, not only changes the perception of performance, but ensures a new way of looking at the relationship between ritual and theatre, and concepts such as culture and play. The theatre work Schechner began in the heated social climate of the late 1950s USA shifted largely to performance research studies after the 1980s. Schechner approached the relationship between theatre and anthropology from different perspectives, and instead of reading performance within the frame of theatre, he read theatre within the frame of performance. Performance, which Schechner views as an inclusive paradigm, enables correlations such as nature-culture and art-life to be read from different perspectives. Fundamentally, Schechner's thought positions itself in opposition to the Western, Anglo-American centred ruling culture and its ideas of restrictions and classifications; a place where 'intersections, interactions, ambiguity' is praised alongside liminality.
\end{abstract}

Keywords: Performance, anthropology, theatre, culture, play, liminal.

Academical disciplines/fields: Performance, theatre, anthropology.

- $\quad$ Sorumlu Yazar: İbrahim Güngör

- $\quad$ Adres: Ergene Mah. 534 Sokak. No: 1/19 Bornova-İzmir

- e-posta: ibrahim.gungor99@gmail.com

- ORCID: 0000-0003-3633-8524

- Cevrimiçi yayın tarihi: 27.05 .2021

- doi: 10.17484 /yedi.853668 


\section{Giriş}

Richard Schechner, 1950'lerin sonundan günümüze uzanan, geniş bir araştırma ve uygulama sahasına yayılan çalışmaları ile performans araştırmaları konusunda öncü isimlerden biridir. Erken dönemlerinde deneysel tiyatro çalışmaları ve aktivist kişiliği ile ön plana çıkan Schechner, 1970'lerin başından itibaren tiyatro teorisi ile sosyal bilimler ilişkisine odaklanmaya başlamış ve performansın çok boyutlu yapısı üzerine araștırmalar yürütmüştür. Bu süreçte antropoloji bilimi ile yakından ilgilenmeye başlar; ritüelleri inceler, tiyatronun kökenine dair teorileri yeniden ele alır ve drama, ritüel, tiyatro, metin ilişkisini yeniden tanımlar.

Bu değişim süreci tek başına Schechner'in kişisel serüveninde yaşanan gelişmelere bağlı değildir. 1960'lar ve 1970 'ler geleneksel tiyatro araştırmalarının sorgulanmaya başladığı dönemler olmuştur. Batıll, AvrupaAmerika merkezli bakışın yarattığı kalıplar sadece tiyatro alanında değil sosyal bilimler alanında da bir kriz ve çıkış yollarının aranmaya başlandığı bir tartışma ortamı yaratmıştır. Tüm bu süreç Richard Schechner'in de aralarında olduğu Grotowski, Peter Brook, Eugenio Barba gibi isimleri kültürel olarak batılı olmayan anlayışları yakından incelemeye ve toplumsal eylemlilikle çözülemeyen sorunlara ritüelistik kökenlerden çözüm üretmeye ya da kültürel olarak alternatiflere daha yakından bakıp, ortaklıklar, benzerlikler veya kesişmeleri aramaya yönlendirir.

Marvin Carlson, Schechner'in çok boyutlu performans araştırmalarına odaklanan The Rise of Performance Studies (2011) isimli çalışmada yer alan makalesinde Kuhn Değişimi'nden söz eder. Thomas Kuhn tarafından bilimsel düşünce için ortaya atılan yaklaşım, genel olarak kabul görmüş düşünce sistemlerinin başarısızlı̆̆a uğraması sonrası yeni bilgilere, yeni perspektiflere ulaşılması için bir arayış ve yeniden uyarlanma dönemi önermektedir. Carlson, Kuhn Değişimi ya da Paradigma Değişimi (Paradigm Shift) olarak adlandırılan egemen, yerleşik yöntemlerden çıkışın kültürel örneğini Schechner'de bulur (2011, s. 16). Geleneksel batı tiyatrosunun araştırma yöntemlerinin yetersizliği alternatif yollar aranmasını zorunlu kılmıştır. Schechner de bu gerekliliği hissetmiş ve önemli bir düşünsel süreç ortaya koymuştur. Özellikle 1970'lerin başında yoğunlaşan, 1980'lerde performans araştırmaları olarak somutlaşmaya başlayan ve geniş bir yelpazeye uzanan çalışmalarıyla yeni paradigma değişiminin tiyatrodaki örneğini oluşturmuştur. Bu süreç antropoloji bilimi ile yakınlaşmasıyla köklü bir teorik altyapı kazanmıştır. Antropolojiden elde ettiği veriler ile yönlendirdiği çalışmaları farklı başlıklarda çeşitli sonuçlar doğurmuş ve performansı sanatın olduğu kadar yaşamın hemen her boyutunu kapsayıcı bir paradigma olarak ortaya atmasını getirmiştir.

Diğer yandan bu paradigmanın kapsayıcı (hatta kimi zaman 'yutucu') özelliği ve 'yine' batı kökenli oluşu çeşitli tartışmaları ve eleştirileri de beraberinde getirmiștir. Çalışma dilimizde yürütülecek tartışmalara/eleştirilere zemin hazırlamak için 'eşiksellik' düşüncesinin perspektifinden bakarak Schechner'in performans düşüncesinin anatomisini vermeyi hedeflemektedir. Bu amaçla, öncelikle Schechner'in antropoloji ile temaslarına ve tiyatro-antropoloji ilişkisi konusunda düșüncelerine göz atılacak sonra performansı okumak için ortaya attığı paradigmanın aynasından bakarak temel yapıtaşları olan 'eşik' (liminal) ve 'yapılandırılmış davranış' (restored behaviour) kavramları ele alınacak son olarak da oyun ve kültürü algılama biçimine odaklanılacaktır. Tüm bu analizler sonrasında ise Schechner'i merkeze alarak performans düşüncesine yöneltilmiş kimi eleștirilere yer verilecektir. Elbette ki çalışmanın amacı Schechner'in görüşlerinin eleştirel bir değerlendirilmesi değildir. Ama burada anatomisi sunulan görüşlerin sınandığı ve kurulan paradigmanın hangi açılardan sorunlu görüldüğünün belirtildiği bir bölümle dilimizde yürütülecek tartışmalar için zemin oluşturma hedefine bir açıdan daha katkı sunulmaya çalışılacaktır. Bu anlamda tüm tartışmaların bir özetini vermek mümkün görünmese de başat bazı sorunsallara ve tartışmanın yürütüldüğü bazı önemli kaynaklara işaret etmenin faydalı olacağı düşünülmektedir.

\section{Tiyatro-Antropoloji İlişkisi}

Schechner'in farklı kültürlere ve onların ritüel, tören yapılarına olan ilgisi 1970'lerin başına dayanmaktadır. Hatta Ritüelin Geleceği (The Future of Ritual) isimli çalışmasında (2015, s. 14-18) bu süreçte, Hindistan'da bir ayini yakından izlemek, gözlemlemek için din değiştirdiğinden ve Jayaganesh adını aldığından söz eder. Antropolojik yaklaşımına yön veren asıl olay ise 1977 'de Victor Turner ile tanışması olmuştur. Daha öncesinde de farklı kültürlerin tören yapılarını gözlemlemekte olan Schechner için, Turner'ın ritüel-drama ilişskisinde ürettiği özgün fikirler yeni perspektifler açmıştır. Bu birliktelik ikilinin performans araştırmalarının 'ortak babaları' olarak anılmaları (Harding ve Rosenthal, 2011, s. 5-6) derecesinde dikkat çekmiştir. Bu diyalog ve araştırma süreci Turner'ın 1983'teki ölümüne değin sürer. 
Schechner bir söyleșisinde (Cutugno, 2013, s. 140) antropoloji ve antropologlar tarafından derinden etkilendiğini söylemiştir. Antropoloji kökenli araştırmaları yaptığı yolculuklar ve gözlemlerle de desteklenmiştir. Schechner bu çalışmaları süresince Güney ve Güneydoğu Asya'dan, Java ve Bali'ye oradan Filipinler, Kore, Yeni Gine'ye kadar pek çok ülkede ritüel, ayin ve performansları izler. Budist rahiplerin, Müslüman dervişlerin, Hint kathakali dansçllarının gösterilerini çözümler.

Schechner tiyatro-antropoloji ilişkisini yeni bir perspektiften okumuştur. Bu bakışı antropologlar üzerinde de derin etki bırakır. Victor Turner, Schechner'in Between Theatre and Antropology isimli çalışmasına yazdığı önsözde (1985, s. ix), antropologların genelde statik olanla, değişmez olanla ilgilendiğini ama kendisinin Schechner'in dinamik, değişime odaklanan bakışından yoğun olarak etkilendiğini söylemiștir. Schechner, tiyatro ve antropoloji araştırmalarının etkileşimini şöyle açıklar: Tiyatro insanları prova yapma, deneme konusunda uzmanlașmıștır, antropologlar ise gözlem yapma konusunda. Bu etkileșimle artık bazı antropologlar gözlemlediğine katılmaya ve tiyatroculardan bu katılımda neye dikkat etmeleri gerektiğini öğrenmeye başlamıștır. Antropologların bakışı ise tiyatro insanlarına, baktıkları performansın hangi sosyal sistemin bağlamında gerçekleştiğini görme şansı verir. Tiyatro ve antropolojinin metotları yakınlaşmakta ve sınırlar hızla yıkılmaktadır (Schechner, 1985, s. 25-26). Tiyatronun antropolojik hâle gelmesi gibi antropoloji de tiyatralleşmektedir (1985, s. 33). Öte yandan Schechner antropolojinin 'öteki' kültürü izleme tarzında batılı-batılı olmayan ikiliğinin yerleşik hâle gelmiş̧ olduğunu söyler. Performans araştırmalarının antropolojik bakışında ise bu ayrım geçersizdir. Performans araştırmacısı kendini de kültürel sürecin parçası olarak, refleksif bir gözle izleyerek, bir 'öteki' olarak çözümleyebilir. Schechner bu mesafeli tutumu Brechtyen bir uzaklık ve eleştiri, ironi ve sempatiye dayalı bir bireysel katılımı da içeren bir süreç olarak açıllar (Schechner, 2013, s. 2).

Schechner, araştırmaları sürecinde pek çok farklı kültürün ritüellerine yakından bakar. Bu noktada ritüeli sadece dinin ya da inancın tarihinin bir unsuru olarak görmez. Yeni çalışmalarla, ritüelin dinle sınırlandırılması düşüncesinden, "insan faaliyetlerinin olușturduğu geniş yelpazeye tatbik edilen bir süreç" (Schechner, 2015, s. 34) olarak görülmeye başlanması önemlidir. Artık "muhtelif performans sahalarını birbirinden ayıran oldukça katı sınırlar delinmiştir" (2015, s. 34). Diğer yandan tiyatroya köken oluşturan törensi yapılar düşüncesi de Schechner'in bakışında tek boyutlu ve sınırlandırıcıdır. Bu noktada Schechner'in tiyatronun kökenine ilişkin 1900'lerin ortasında Cambridge Üniversitesi'nde yapılan araştırmalar üzerine düşüncelerini belirtmek gerekmektedir: Schechner tiyatronun ritüelistik temelin üzerine inşa edilmiş ya da ritüelden gelişmiş bir tür olduğu ile ilgili genel yaklaşımı kanıtdışı görür. Ritüelden Dithyrambos şarkılarına ve oradan da tragedyaya dönüşüm iddialarını zayıf ve bağlantısız bulur. 'Köken'e iliş̧in kapsayıcı bir teoriyi reddeder. Schechner'e göre ritüel tiyatroya bağ oluşturmuş etkinliklerden sadece biridir. Bunun dışında oyun (play), eğlence (game) ve spor gibi etkinlikler de aynı derecede etkilidir. Ögeler arasında kesin sınırlarla bir ayrımdansa kesişen, iç içe geçen ve etkileșen bir yapı görür. Tiyatronun bu etkinliklerin ardılı olduğunu düşünmek sadece Batılı Yunan dramı üzerine düşünmek anlamına gelmektedir. Oysaki olay anlatımı, canlandırma pek çok farklı kültürde farklı biçimlerde oluşmuştur. Hatta bazı kültürlerde insanın kamusal performans etkinlikleri o derece iç içe geçmiştir ki bunlara Batılı anlamda bağımsız isimler vermek zorlaşır (Schechner, 1966, s. 26-27). Schechner bu düşüncesinin sonucu olarak Doğu performans sanatının ilk metni olarak kabul edilen Natyasastra'ya yakından eğilmiş ve onu incelemiştir. Natya, Sanskritçe'den batı dillerine çevrilmesi çok kolay olmayan bir sözcüktür. 'Dans-Tiyatro ve Müzik'i bir arada barındıran bir anlamı vardır (Schechner, 2003, s. 334). Batılı anlamda oluşturulmuş katı sınırların geçerliliğini yitirdiği örneklere duyduğu ilgi Schechner'in yeni paradigmasının da ana eksenlerinden birini oluşturacaktır.

Ritüel ve tiyatro ilişkisini incelerken, Schechner merkeze yararlı olan ile eğlenceli olan karşıtlığını koyar. Ama ikisi için de kesin sınırlar çizmez. Ritüelde yararlılık ön planda iken tiyatroda eğlence öne çıkar. Performans, bu noktada, ritüelin de tiyatronun da temelinde yer alan kapsayıcı ögedir. Schechner'in From Ritual to Theatre and Back (1974) isimli makalesinde ritüel-tiyatro ilişkisi şu başlıklarla özetlenir:

1) Bazı toplum düzenlerinde ritüel performanslar ekosistemin parçasıdır ve politik ilişkilere, grup yapılanmasına ve ekonomiye aracılık eder.

2) Öteki düzenlerde ritüel performans şov dünyasının özelliklerinin sorumluluğunu üstlenmeye başlamıştır.

3) Yararlılık ve eğlence arasında diyalektik bir bağ vardır. Bütün performanslarda her ikisi de vardır. (...)

4) Ama farklı toplumlarda farklı zamanlarda yararlılık ve eğlence arasında domine eden taraf değişir (...) (Schechner, 1977, s. 78). 
İbrahim Güngör

Ritüel ve tiyatronun yarar ve eğlence açısından temel bulduğu kuruluş özellikleri ise şöyledir:

1) Ritüel: Komünal, gerçek, güncel ve yararcıdır.

2) Tiyatro: Bireysel, kurgusal, mimetik ve eğlencelidir (Schechner, 1977, s. 66).

Bu yarar/ritüel ve eğlence/tiyatro yapısını ise bütünsel olarak performans olarak tanımlar (1977, s. 87).

Schechner, ritüel ve tiyatro ilişkisinin diyalektik bir şekilde ve iç içe okunması gerektiğini düşünmektedir. Tiyatro yaratım süreçlerinin ritüelleşmesini veya ritüelin eğlence ve toplumsal eleştiri barındırmasını örnek verir (Schechner, 2015, s. 74). Schechner genel olarak Victor Turner'ın ritüeli algılama biçiminin izinden gitmektedir. Turner'ın ritüeli 'ortada bir yer'de, arada, eşikte konumlandırdığını söyler. Boşluklar ve kıvrımlar oyunla dolarak ritüel özellik kazanırlar. Ritüel süreç Turner'ın bakıșında "liminal-liminoid, yetkisiz, yapı-karşıtı, koşullu ('eğer') ve yıkıcıdır" (2015, s. 291). Liminal ile liminoid arasındaki fark ise şöyledir: Arnold van Gennep'in 'eşik' olarak tanımladı̆̆ı liminal'i Victor Turner detaylandırır, katmanlandırır. Liminal zorunlu etkinliklerde kullanılan 'eşik' iken, liminoid boş zaman ve sanatsal olanda yer alan eşikselliktir. Örneğin Grotowski'nin ritüel denemeleri liminoid olarak görülür (2015, s. 292). Fakat buradaki köşeli ayrımı savunmayan Schechner'in pek çok farklı makalesinde ana olarak vurguladığı nokta ritüel-tiyatro, yarar-eğlence ilişkisinin iç içe geçmişliği ve sürekliliğidir. Bu noktada sanayi toplumunun işlevleri, etkileri ayırıp sınıfladığını söyler. Komünal toplum ise bir araya getirip, karmaşıklaştırmaktadır. Örneğin șamanlar hem sanatçı hem performansçı hem doktor hem büyü altındaki hasta, hem rahip hem de eğlendiricidir. Öyledir çünkü pek çok farklı itkiyi bir arada barındırırlar (Schechner, 1977, s. 88-89). Ritüel ve tiyatronun ilişkisini incelerken Orta çağ kilise gösterilerini örnek verir. Bu yapıların Avangard sanata benzerliğine dikkat çeker (1977, s. 78). Modernist sanatın örnekleri olan Avangard sanata benzerlikleri, onların asıl doğalarındaki ayinsel ve dinsel yapının üzerinde okunabilmektedir. Ama benzerliğe rağmen bu gösteriler ritüele daha yakın görülürler. Burada dikkat çekmek istediği şey tiyatro tarihçilerinin kolaylıkla bağlamından kopararak tiyatroya ait bir değerlendirme ile okudukları Orta çağ gösterilerini hem tiyatroritüel aralığında tutması hem de toplumsal anlamının içinde değerlendirmesidir.

Schechner, çağdaş tiyatronun en önemli gelişmelerinden birinin sosyal roller ile dramatik rollerin birbirine ne kadar bağlı olduklarının fark edilmesinde yattığını söyler. Yazarın aklında, soyut bir alanda kurulan yakınlaşmadansa, sahnelemede (uygulamada-mise en scene) yararlı olan ile eğlenceli olanın dengelenmesinin, çağdaş tiyatronun önemli adımlarından birini oluşturduğunu düşünür. Eylemlerin, gerilla hareketlerinin, terör hareketlerinin dikkat çekmek için tiyatralleşmesini bu nedene bağlar (Schechner, 1977, s. 70). Yarar beklentisi eğlencenin alanına girerek dikkat çekmeye çalışmakta, aynı zamanda işlevinden uzaklaşmamaktadır. Ritüel ve tiyatro arasındaki farklardan bir diğeri de toplumsal yaşamdaki işlevlerindedir. Yarar ve eğlence dengesi dışında biri inanmak diğeri inandırmak temeline kuruludur (aktaran Epskamp, 2003, s. 501-502). Schechner'e göre ritüel'in 'ne'liğinin bilinmesi, ritüelden tiyatroya gelişimin en önemli adımlarından biridir. Schechner'in hedefi kesişimleri, bazen ritüelin tiyatroya neden olduğunu ve bazen de tiyatronun ritüelleşme yarattığını göstermektir (Schechner, 1977, s. 68). Schechner'e göre ritüelin tiyatroya dönüşümü günümüzde bile devam etmektedir. Bugünden bakıldığında tiyatronun temel farkı seyirci-performe eden konusunda yaptığı kesin ayrımdır. Ritüel katılımcıların bağımlı olduğu bir yapı iken, tiyatro katılımclara bağımlı bir yapıdır (Schechner, 1977, s. 79).

Schechner, Batı'nın ve Doğu'nun tiyatrosunu farklılıkları çerçevesinde okur. Batı tiyatrosu karakterizasyona ve kurguya vurgu yapan bir tiyatrodur. Afrika, Malezya, Avustralya tiyatrosu ise daha ritüelistik bir yön taşıyarak düşmanca davranışın uzaklaştırılmasına yöneliktir. Bu iki yapı No, Kathakali, Bali tiyatrosunda dengelenmektedir. Schechner geleceğin tiyatrosunun bu dengeleyici yapıda yattığına inanmıștır (Schechner, 1977, s. 66).

Dengeleyici bir yapı arayıșı tüm kültürleri tek bir ortak noktaya getirme amacı gütmemektedir. Bu noktada Carlson'un da belirttiği gibi, Schechner'in amacı bütün kültürlerin erişimine açık ritüel kökler aramaktır. Çünkü özellikle Batı tiyatrosunun seyri bireyselciliğin, ticarileşmenin boyunduruğuna girmiştir. Ve basitçe diğer toplumların geleneksel tiyatrosunu yaratmanın bir yolu yoktur (Carlson, 2007, s. 490). Schechner'in farklı olanın nasıl ortaya çıktığını ve bunun günümüz batılı tiyatral yaklaşımın çıkmazlarında ne gibi açarlar sağlayabileceğini ve bakışı nasıl değiștirebileceğini araştırdığı görülür. Bu nedenle kökenlere inerek farklı kültürlere ait ritüellerin incelenmesi Schechner'in çalışmalarında önemli bir yer tutar.

Bu noktada Victor Turner'ın belli çözümlemeleri Schechner'e öncü olmuştur. 
Victor Turner bütün ritüel yapılarda benzer bir şablon görür. Bu çözümlemesinde Arnold van Gennep'in The Rites Of Passages (Geçiş Ritleri) (1908) kitabında açılkladığı yapının izinden gitmektedir. Turner,

1) İhlal

2) Kriz

3) Onarıcı eylem

4) Yeniden kazanma (yeniden entegre etme)'nin hem toplumsal süreçte hem de tiyatroda evrensel olarak var olduğunu söyler (aktaran Schechner, 1977, s. 140).

Schechner'e göre tiyatronun kökeni, klasik batı algısının önerdiği gibi 'çatışma'ya değil ‘dönüşüm'e dayanır (Schechner, 1977, s. 194). 'Dönüşüm' ise Victor Turner'ın Gennep'ten ödünç aldığı 'kriz' bölgesinde gerçekleșir. 'Eşik' (liminal) olarak görülen bu bölge aynı zamanda eşik öncesi ve eşik sonrasını birbirinden farklılaștırır. Yani 'eşik', 'dönüşüm' sürecini yapısında barındırır. Gennep'in 'geçiş ritleri' olarak ifade ettiği törenler süresince toplumdan kopmuş ya da koparılmış kiși kriz bölgesinde ne kendisidir ne de bir başkası. $\mathrm{Bu}$ 'eşik' süresinin sonunda geri kabul edilmesi için dönüşmesi ya da onarılması gerekmektedir. 'Eşik/eşiksellik' düşüncesine çalışmanın ilerleyen bölümlerinde detaylı olarak odaklanılacaktır.

Schechner'in bu görüşleri yaklaşımının kimi özelliklerini göstermektedir: Genel olarak kültürel bir hegemonyaya sahip Batılı söylemin dışında daha kapsamlı bir ortaklık, benzeşlik arayışına girdiğini ve bunu yaparken de insanın toplumsal, komünal temellerine yöneldiğini görmek mümkündür. Bu ortak özellik arayışı onun döngüsel benzerliklere duyduğu ilgiden dolayıdır. Schechner, Doğu ile Batı'nın tarihsel gelişim sürecindeki farklılaşmaları kadar, bugünün yapısı ile ritüel estetiğinin kesişim noktaları ya da soyaçekimleri üzerinde durur (Cutungo, 2013, s. 143). Bakışındaki temel dürtü ayrllıklar, farklardan çok benzerliklerin yakalanması üzerine kuruludur (2013, s. 144). Ama bu, Schechner'in bu benzerlik algısında her șeyin aynı ve eşit olduğunu söylediği anlamına gelmez; her şeyin bir bütünün parçaları olduğu ve sayısız değiş-tokuş ve dönüșümün mümkün olduğu anlamı üzerinde durmaktadır (Schechner, 1977, s. 43). 1960 sonrası sanatın ve sanatçının 'market' koşullarına uyarlanmaya başlaması, bireyselciliğin artması ve egemen kültürün tek tipleşme tehdidi Schechner'i alternatif görüşlere yönlendirmiştir.

Bu nedenle Batılı anlamda dram sanatının hâkim etkisini tartışmaya açar. Tiyatro, senaryo (script) ve performans'ı evrensel görebiliyorken dramanın bir bölgeye ya da zamana özgü olduğunu iddia eder. Kavram olarak hepsi tarihöncesidir. Fakat drama öncesi ritüel, ayin düzeninde performanslar topluluğun doğal yaşam karşısındaki birliğini temsil etmekte yani kurtarıcı bir nitelik taşımaktadır. Öncelikli amaç iletişim değil, durumun ya da çözümün ortaya konması, sahnelenmesidir. Schechner bu sürece 'deklare etme' der. Eylemsellik performansın en önemli ögelerinden biridir. Fakat yazının icadı bu durumu değiştirmiştir. Drama eylemsellikten uzaklaşılmasına ve sözel bir iletişimin baskın çıkmasına neden olmuştur. Deklare etme/ortaya koymanın yerini iletişim almıştır (Schechner, 1977, s. 37-38).

Bu noktada drama, senaryo (script) ${ }^{1}$, tiyatro ve performans ilişkisini bir görselde özetler (Bkz. Şekil 1).

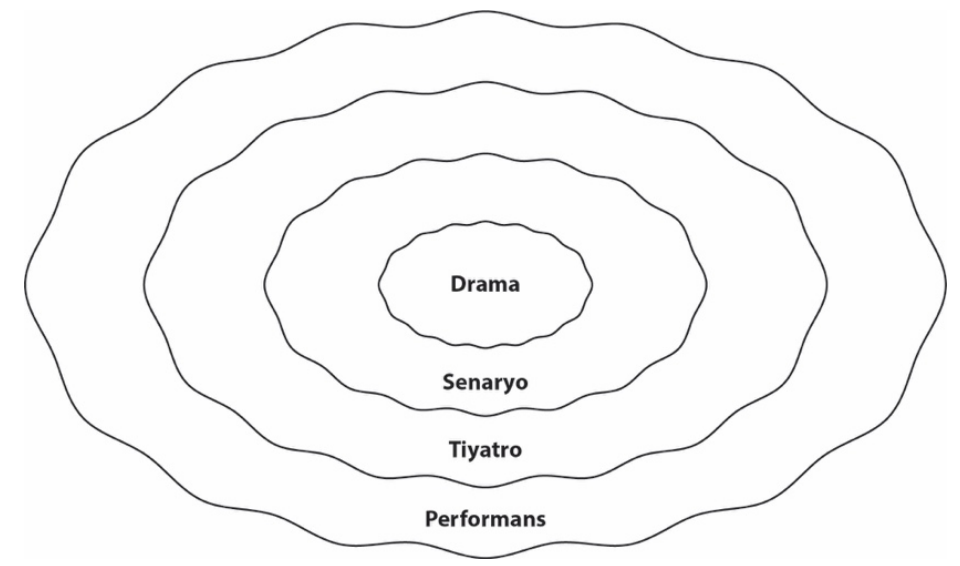

Şekil 1. Drama, senaryo (script), tiyatro ve performans ilişkisi (Schechner, 1977, s. 33).

\footnotetext{
${ }^{1}$ Senaryo olarak çevrilen script sözcüğü, Schechner'in kullanımında eylemler dizgesini ya da özellikle modern dönemde yaygın olarak metinden ayrı düşünülemeyen olay dizgesini kapsar şekilde kullanılmaktadır. Hemen öncesinde bahsi geçen drama ise tam olarak yazilı metni kapsamaktadır.
} 
Marvin Carlson, Schechner'in ortaya koyduğu bu 4 yapının iç içe geçen ilişkisini şu şekilde özetlemektedir:

Schechner; (...) dram ya da orijinal metin; metinden yeni bir duruma iletilebilecek senaryo (script); performans sanatçılarının gerçekleştirdiği belli bir olay olan tiyatro ve bu olayı kuşatan insan etkinliğinin bütün konstellasyonu olan performans arasında ayrım yapıyordu. Geleneksel yanılsamacı tiyatro bunları bir arada kaynaştırmaya çalışırken modern deneyler sıklıkla bunların arasındaki 'bağlantı yerlerine' ya da ayrılıklara dikkat çekiyordu. (Carlson, 2007, s. 505)

En temelde Schechner dram sanatının ve senaryonun avcı ritlerine dayanan toplumlara, performans ve tiyatronun ise tarım toplumlarına özgü olduğunu öne sürer. Avcılığın stratejilerinde geleceğe dönük bir davranış oluşturulabilmesi adına stratejik bir dil kullanılır: hikâye anlatıcılığı. Burada bahsettiği sadece yazılı anlamda bir yapı değildir, aynı zamanda dans, şarkı, ilahi (zikir), davul sesleri ve mekân düzenleme (mağara duvarları örneğinde olduğu gibi) kullanılır. Yani Schechner'de dramanın, stratejik davranışın bir sonucu olarak ele alındığı söylenebilir. Schechner'in çıkarsamasına göre performans ve tiyatro evrensel iken, drama değildir. Drama, performans ve tiyatronun bir bağımsız örneği olarak gelişmiş olmalıdır (Schechner, 1977, s. 60).

Genel olarak bakıldığında antropoloji ile kurduğu yakınlıktan elde ettiği veriler Schechner'i performansın kapsayıcı çatısını daha derinden araștırmaya yönlendirmiştir. Ritüel-tiyatro ilişkisine bakarken her ikisini saran bir yapı olarak performansı görmüștür. Tiyatronun 'performans' alanının bir alt başlığı olarak değerlendirilmesini istemesi (aktaran Auslander, 2002, s. 2) de bu nedenledir. Nitekim uzun yllar editörlüğünü yaptığı The Drama Review dergisinin alt başlığını The Journal of Performance Studies olarak güncellemiş ve New York Üniversitesi'nde Performans Araştırmaları Bölümü'nün kurulmasına ve çok kapsamlı çalışmalar yapılmasına öncülük etmiştir. Bu anlamda üniversitelerin programlarının anahtar bir paradigma olarak 'performans'a yönelmesinin ve siyaset, tıp, din, popüler eğlenceler ya da gündelik hayattaki kullanımları üzerine çalışmalar yapılmasının önemine özellikle vurgu yapmıştır. Performans düşüncesi "kültürel bir analiz aracı" (Schechner, 2010, s. 49) hâline gelmelidir.

\section{Bir Eşiksellik Paradigması: Performans}

Schechner, 1980 sonrası çalışmalarında temel izlek olarak 'performans'ın alanının, genel işlev ve anlamının araștırılmasını odak almıştır. Sadece sanat ya da estetiğin alanında yer alan veya tiyatral değerlendirmenin bir unsuru olarak performans düşüncesini terk eder. Schechner'e göre spor müsabakalarından mesleki faaliyetlere, popüler eğlencelerden, performans sanatlarına, gösterilerden günlük işlere kadar pek çok noktada performans vardır. Bu noktadaki düşüncelerinin temelini Erving Goffman'ın Günlük Yaşamda Benliğin Sunumu (2009) isimli çalışmasında açlkladığı görüşler oluşturur: Goffman günlük hayatta toplumsal ilişkilerin bir sunum mantığı içerdiğini ve bu sunumların performans olarak nitelenebileceğini söyler. Temelde ortaya koyduğu, gündelik hayata tiyatronun yansıması değildir. Daha çok insanların "gerçek toplumsal durumları sürdürmek için başvurdukları teknikler (...)" (Goffman, 2009, s. 236)'den bahsetmektedir. Goffman bu noktada sahne, oyuncu, sahne arkası, dramaturji, rol, kostüm, dekor, seyirci gibi tiyatronun temel kavramlarını ödünç alır. Schechner de performansın özerk/ilişiksiz bir tür olmadığını, toplumsal ilişkilerin kökeninde yer alan bir özellikte olduğunu düşünmektedir. Schechner'e göre insanın performansa dayalı davranışları, genel olarak ritüelleşme eğilimindedir. Yani performansın yinelenen, tanınabilir, tanımlanabilir süreçleri vardır. Bu ögeler ritüellerde görülebildiği gibi, tiyatroda, günlük hayatta, siyasette, sporda yani yașamın pek çok anında görülmektedir. Schechner bu süreçleri yedi bașlıkta özetler: Eğitim, atölye ve provadan oluşan süreçten sonra performans ânı gelir. Performans ısınma ve sunumdan oluşmaktadır. Sonrasında ise rahatlama ve sonuç gelir. Araștırmalarında performans olan ve olmayan sınırına yanıtlar üretmeye çalıșır. Katı bir ayrım arayışındansa, tanınmayı sağlayacak unsurlar ve performansı ortaya çıkaracak 'bağlam'ın önemi üzerinde durur. Örneğin bir tiyatro sahnesi performansa mekân olabileceği gibi gösterim olmayan bir zamanda üzerinde zaman geçiren biri ile performans dışı bir mekâna da dönüşebilir ya da günlük hayatın sıradan gibi gözüken bir eylemi küçük bir değișimle bir performans özelliği kazanabilir. Schechner bir söyleşisinde bu tanımlanabilme durumunun altını özellikle çizmektedir: "(...) belirli bir şeyin sadece kendisine bakarak onun bir performans olup olmadığını söyleyemezsiniz. Bu; o anki şartlara, nasıl gösterildiğine, nasıl algılandığına vs. bağlı olarak değișir" (Dalyanoğlu, 2010, s. 28).

Öte yandan performansın sürecinin tanımlanabilir ögeleri gibi üretiminin de temel ögeleri vardır. Bunlar 'eșiksellik' ve 'yapılandırılmış davranış'tır. 'Eşik' daha önce de söylendiği gibi bir 'aradalık' hâlidir. Schechner, performe etmenin 'bir eşiksellik paradigması' olduğunu söyler (Schechner, 1985, s. 123). 'Eşik' 
(liminal) ya da 'aradalık' Arnold van Gennep'ten Victor Turner'ın kullanımına aldığı ve ondan da Schechner'in performans teorisi için devraldığı bir kavramdır. Turner'ın kullanımında 'eşik' bir 'muğlaklık' hâlidir. Eşikteki kişiler "durumları ve konumları kültürel uzama yerleştiren sınıflama ağına takılmazlar" (Turner, 2018, s. 96). Toplumsal tanımlara, sınırlama, sınıflama ağına takılmama hâli yerleşik düşüncelerin ve statü ilişkilerinin dışında ele avuca sığmaz bir 'aradalık' ifade etmeye başlar.

'Eşikselliği' sağlayan ise ritüel ve tüm diğer performansların kökeninde yer alan 'yeniden yapılandırılmış davranış'tır (restored behaviour). Bütün toplumsal süreçler en küçük birimine kadar ayrıştırıldığında geriye bazı davranış birimleri kalacaktır. $\mathrm{Bu}$ birimler çeşitli performans etkinliklerinde yeniden yaratılmaktadırlar. Schechner'e göre bütün kültürlerde performanslar ikiliğin/yaplandırılmış davranış olma durumunun özelliğini paylaşırlar (Schechner, 1985, s. 52). Bu noktada Schechner'in davranış birimlerini toplumsal ilişkiler açısından bir kök olarak gördüğü söylenebilir. Performans yaratımları bu davranış birimlerinin yeniden yaratılması, ikilenmesi, prova edilip yapılandırılması üzerine kuruludur. Schechner'e göre zaten tarih de yaşanmış olayların bir dökümü değildir. Tarih olayların ötesinde inşa edilenlerdir: hatıralar, kayıtlardır. Kişilerin dünya görüşünce şekillenen -bireysel veya kolektif- kodlanan ve performe edilen yapı tarihi oluşturur. 'Tarih yapmak' bir şey eylemek değil, eylenen bir şeyi yinelemektir (Schechner, 1985, s. 51). Dolayısıyla tanımlanmış ya da tanımlanmamış tüm performanslar en azından bir ortak temel nitelik taşırlar. Bu temel nitelik performans davranışı, denenmiş, yinelenmiş, prova edilmiş, yeniden yapılandırılmış, önceden bilinen davranış olarak adlandırılır. Schechner performans davranışının basit ve başıboş, sadece performansçıya ait ve bağlı olmadığını söyler. Bu yaklaşım temel olarak bireysel yaratımla ilgili sanatın özerkleşme tavrına karşıt bir yan barındırır. Örneğin özellikle Avrupa-Amerika tiyatrosundaki (Stanislavski ve sonrası) prova ve çalışma sonucunda ulaşılan 'mış gibi' yaklaşımı performans davranışını performe edene bağımlı kılmaktadır (Schechner, 1985, s. 118). Onu bütünlüklü toplumsal yapısından ve kökeninden koparır. Schechner'in 'yeniden yapılandırılmış davranışlar'ı ise hem performansı hem de icra edeni bir toplumsal yapı, geçmiş ve gelecek ilişkisi içerisinde değerlendirmeye olanak sağlar.

Şimdi tam da bu noktada daha önce bahsi geçen eşiksellik (liminality) durumuna yeniden dönülmesi gerekmektedir. Kriz durumundaki kahramanın 'ne topluluğa ait olmak ne de olmamak, ne kendi ne öteki olmak ya da ne gerçek hayattaki konumunda ne de kurgusal bir kişilikte olmak' arasındaki bölge eşiktir. İkisi ortası (betwixt-and-between) olma durumu, aynı zamanda, Schechner'in performansı 'bir eşiksellik paradigması' olarak açıklarken ortaya attığı, terminolojisinde önemli yeri olan 'ben değil', 'ben değil değil' (not me...not not me) kalıbında görünür olur. Bu kalıp tam olarak eşikselliğin performansta nasıl karşıllı bulduğunun okunmasını sağlar. Performans esnasında artık bir 'ben' yoktur ama bir 'ben olmayan' da yoktur. Schechner'in slkça örneğini verdiği üzere (1985, s. 110, 123) Laurence Olivier, Hamlet'i oynarken kendisi değildir. Ama Hamlet de değildir. Öte yandan Hamlet olmayan da değildir. Bu 'ben' ile 'ben olmayan' arasında bir 'aradalık' hâlidir. Schechner tarafından 'ikili olumsuz ilişki' (double negative relationship) olarak ifade edilen (1985, s. 112) 'o değil', 'o değil değil' yapısı 'yeniden yapılandırılmış davranış'ın hem bireysel hem de sosyal olan yapısını açığa vurur. Davranış bir yandan o an ilk kez yapılmakta ama diğer yandan o davranış, pek çok kez yinelenmiş öncüllerinin bir tekrarı olarak yeniden yapılandırılmaktadır. Performans, performansçının 'bu ben değil, ama ben değil de değil' durumu temeline kuruludur; performe edenin kendi ile kurması gereken bir 'aradalık' ilişkisine dayanır. Öte yandan performans, performansçılar ve metin arasında, performansçılar metin ve çevre arasında, performansçılar, metin, çevre ve izleyici arasında meydana gelir (1985, s. 113). Yani bir eşiksellikler ağı ile sarılmıştır.

Postmodern dönemin de bir getirisi olan bu belirsizlik, sınırsızlık durumu yapı ile yapıdışını bir arada tutar. 'Yeniden yapılandırılmış davranış' da yeni olan ile aslında yeni olmayanı, hep yineleneni, tarih dışını ifade eder (Bial, 2011, s. 86). Yani 'yeniden yapılandırılmış davranış' performansın eşikselliğini yaratan unsurdur. Bu eşik de tıpkı Turner'ın eşik (liminal) algısında olduğu gibi kişinin dönüşümü için önemli bir alandır. Performe eden kiși 'yapılandırılmış davranış' ile kendini, kendinin dışına çıkarak ve 'ötekiler' ile tanışacağı bir sosyal alana girerek kurtarır (iyileștirir) (Schechner, 1985, s. 112).

Tiyatro da yeniden yapılandırılmış davranışta belirli tekniklerle uzmanlaşılan bir sanattır. Bir tiyatro hazırlığı gestus kalıplarının, seslerin, hareketlerin görünür olan bir duyguya -moda- ulaştırılmasını içerir. Öteki olan 'davranış', performansçının himayesine geçer. Performansçının kendisine yabancılaştığı ya da nesneleştiği yanları -öz benliği ya da kamusal benliğinde- benzeştirilir ve kamusal olarak sergilenir. Bu durum eski ve yeni olanın birleștirilmesidir (Schechner, 1985, s. 99).

Schechner 'yeniden yapılandırılmış davranış'ın performansa özgü olduğunu belirtir ama burada Goffman'ın günlük yaşamda performans içeren, sunum içeren davranışlar olduğu yönündeki düşüncesi ile de temas kurar ve bu ayrımın çok katı olmadığını ama 'belki de' diyerek performans ya da ritüelin daha fazla tekrar 
eden, yinelenen, ikilenen davranışa dayandığını söyler. Bunun karşısına da Schechnervari bir 'aradalık' koyarak belki de gündelik yaşamın 'yinelenen davranışları' bu kadar fazla içermesinden kaynaklı çok daha fazla 'sanat' dolu olduğunu söyler (Schechner, 1985, s. 52). Zaten bu kesişmeler sanat-hayat ya da eğlenceyarar ikiliklerini kıracak mantığı getirecektir. Victor Turner ile beraber şu kanıya varırlar: "Her toplumsal eylem estetik bir bileşene sahiptir ve her estetik temsil de aynı zamanda toplumsal bir şeydir" (Dalyanoğlu, 2010, s. 30).

\section{Oyun}

Schechner'e göre Batı dünyası genel olarak 'oyun'u boş iş, aylaklık, sahtelik, gevşeklik, özgün olmama ve hilecilik ile açıklar. Batı'da oyun 'kof bir kategori' olarak görülmektedir, çünkü “oynamanın çoklu gerçekliğinin gerçek-dışı bir yapmacıklıktan 'otoriteye amade gerçekliğe' kadar uzandığı, piramit şeklinde, giderek artan bir gerçeklik hiyerarşisi içine" (Schechner, 2015, s. 42) yerleştirilmiştir. Oysaki Schechner'in de savunduğu gibi ritüel ile oyun estetik teorinin temelinde görüldüğünde 'oyun'un değeri daha net okunmaktadır.

Schechner, Huizinga'nın Homo Ludens'de (2013) ortaya attığı oyunun kökensel ișlevi düşüncesine bir açıdan karşı çıkar. Schechner'e göre Huizinga oyunun işlevini tartışmanın, onun biricik doğasını/kendiliğindenliğini tartışmak olduğunu düşünmektedir. Oysa Schechner bir işlev arayışını gereksiz görür. Huizinga ile, oyunun insanoğlunun koşulları ile var olduğu konusunda hemfikirdir. Ama Schechner'e göre $(1977$, s. 53) onun biyolojik işlevi, -kurtarıcı değeri- üzerine tartışmak onun inşasını anlamaya yardımcı olacaktır.

Ritüelden söz ederken bazı hayvan türlerinde ritüelleşmiş davranışın fazlaca bulunduğunu söyler. Arı ve karınca gibi hayvanların katı bir ritüelistik yaşama sahip olduklarını belirtir. Fakat tavırlarında 'oyun'a hiç yer yoktur. Bu noktada Schechner önemli bir ayrıma vurgu yapar. Pek çok türde ritüelistik yapıya rastlanırken gelişmiş türlerde ritüel ile oyun yapısı birbirine yaklaşmakta ve iç içe geçmektedir (Schechner, 1977, s. 53). Örneğin bir kedi fare ile oyun oynar. Aynı zamanda onu öldürmek niyetindedir. Şempanzelerde oyun ile agresifleşme oldukça iç içe geçmiştir. İnsanda ise bu yapı iyice komplikeleşir. Bu noktada türün gelişmişliği arttıkça oyun-ritüel yapısının da karmaşıklaştığına dikkat çeker (1977, s. 58). Ve kabul edebileceği yegâne estetik teorinin "oyun ve ritüelin belirgin düzenlendiği bir yapı olduğu hâli" (1977, s. 53) olduğunu söyler. Bu anlayış estetiğin oluşunu 'boș zaman'da, 'lüks'de bulan anlayıșa da bir karşı-cevaptır (1977, s. 51).

Schechner'in yaklaşımında 'oyun'un değeri ile ilgili Batılı yaklaşıma alternatif, Sanskrit dilinde 'yanılsama' ve 'oyun' anlamlarında kullanılan maya ve lila sözcükleri üzerinden verilir. Schechner'in O'Flaherty'den aktardığına göre (1985, s. 44) maya, 'ma' -yapmak- kökeninden gelmektedir: 'dünyayı yaratma', 'bileşenlerine ayırma' ve 'kaostan çıkararak bulma hissi' olarak özetlenebilir. Sanatçılara, sihirbazlara, tanrılara atfedilir. Ama bazı Hint kökenli felsefeler yaşamın her anında insanların gerçekleştirdiği bir şey olarak algılar. Lila ise oyun, spor, drama anlamına gelen bir kelimedir. Schechner'e göre "maya ve lila birbirini yaratır, kapsar ve yansıtır; tıpkı kendi kuyruğunu yutan bir yılan gibi” (Schechner, 1985, s. 44). Oynama maya-lila üzerinden ele alındığında sınırları kalın çizgilerle çizilemeyecek bir yapım ve yıkım, bir yaratıcılık ve değişkenlik olarak görülür. Batılı pozitivist ayrımlar maya-lila ilişkisinde geçerliliğini yitirmektedir. Oyun kendini sanat, ritüel, performans alanlarında gösterir. Yani performans 'oyun'un örneklenmesi hâlidir. (Schechner, 1985, s. 57-58). 'Oyun' sınırları yıkan yapısı ile 'eșik'lerde hareket eder. Bir çalıșma ânının çatlaklarından sızabildiği gibi günlük yaşamın herhangi bir ânını işgal de edebilir. Schechner'in performans anlayıșının eşiksellik terminolojisinde 'oyun' çok önemli bir yer tutar. Çünkü “(...) bir oyun oynamak, resmi kültürün yetke, istikrar, ciddiyet, kalıcllık ve ölümsüzlük gibi iddialarına meydan okur" (Schechner, 1985, s. 64). Dönüşümün gücünü içinde barındırır: "Oyunda' olmak, bütün ilişkilerin geçici olduğunu kabul etmektir" (Schechner, 1985, s. 50).

\section{Kültür}

Kültür ile ilgili genel düşüncesi 'saf' kültür olamayacağı yönündedir (Schechner, 1989, s. 151). Ödünç almanın insan türünün doğasında olduğunu söyler (1989, s. 157) ve hem tarihsel hem çağdaş hiçbir kültürel yapının 'sadece kendisi olarak' kalamayacağını düşünür. "Yabancılar tarafından etkilenmemiş kültür olamaz" (1989, s. 155) der. Bu nedenle kültürün değişim ögesindeki unsurlar üzerinde durur. Kültürlerarasılığı önemser ve uluslararasılığın karşısına önemli bir değer olarak koyar. Bu noktada ne sömürücü bir 'market' kültüründen ne de egemen kültürün asimile edici, eritici ya da koruma adı altında ötekileştirici bakışından yanadır. Schechner "bir dizi kurallarla işleyen bir çeşit değişim düzeni yolunu" 
(1989, s. 152-153) tercih eder. Ona göre tarihin kendisi kültürlerarası bir ilişkiler ağıdır (1989, s. 157). Şimdi insanların yeniden bu düzeni öğrenmeleri gerekmektedir.

Kültürel olarak 'öteki'ne bakarken Schechner'in ana mottolarından biri ilgilendiği, araştırdığı kültürel yapılardan materyal taşımamaktır. Yani nesnelerle değil süreçlerle ilgilenir. Bir Chau ya da Noh maskını ya da Kathakali adımını çalışmalarında kullanmak taraftarı değildir. Schechner'in düşüncesini Peter Brook ya da Eugenio Barba'nın düşüncesinden ve uygulamalarından ayıran yanlardan biri budur. Schechner, Brook ve Barba'nın çalışmalarının, bir ortak payda bulmayı amaçladığını, kendisinin ise 'önsel anlamlı davranış' (pre-expressive behavior) arayışında olduğunu söyler. Ayrıca Schechner kültürel farklılıkları daha dikkat çekici bulmaktadır. Kültürlerarasıllı (interculturalism) ile çokkültürlülük (multiculturalism) arasında somut bir ayrım yapar ve diyalektik bir bakıșla iki yaklaşımın da olumlu-olumsuz taraflarını ortaya koyar. Ona göre çokkültürlülük, kültürlerin bir arada eșit bulunduklarını ama aynı olmadıklarını varsayan teoridir; bir kültür mozaiği görüntüsüdür, kültürlerin eridiği bir pota değildir. Ama bu bakışlar geçirimsiz olduğu için statik, tamamlanmış (kesin) ve süreçsiz bir yapı görünümü verir. Çokkültürlülügün hareketsiz, geçirimsiz bir görünümü vardır. Deneye dayanmayan ve gelişimlere açık olmayan bir dünya görüntüsüdür (aktaran Epskamp, 2003, s. 506).

Kültürlerarasıllkta ise 'şey'ler hareket hâlindedirler, birbirleri ile zıt düşerler, gelişen bir süreç yaratırlar. Kültürlerarası bir dünya daha fazla çeşitlilik ama daha fazla risk ve tehlike barındırır. Egemen kültürün asimile edici gücü ya da melezlenmelerin yaratacağı değișiklikler kültürlerarasılığın 'değişim' odaklı yanını oluşturur. Bu nedenle Epskamp'a göre Schechner kültürlerarasıllğı bir büyük yap-boz ile özetlenemeyecek, ona uymayacak ya da sığdırılamayacak birçok kültürlü yapı olarak görür. Schechner kültürlerarasılığa karşı değildir ama güçlü kültürün etkisi ya da eski kolonyal hareketlerin yerini alan globalleşmenin getirdiği 'politik doğru'nun etkisini de tehlikeli bulur (Epskamp, 2003, s. 507-508).

\section{Schechner'in performans düşüncesini tartışmak için bir zemin sunmak}

Performans çalışmalarının 1980 sonrası yaygınlaşması ve kısa sürede tüm dünyada bir araştırma ve tartışma başlığı hâline gelmesi aynı zamanda bir eleștirel dizgeyi de tetiklemiştir. Schechner, daha önce de bahsedildiği gibi, Victor Turner ile beraber ortaya attı̆g yapı ile bu fikrin 'ortak babaları' olarak adlandırılacak derecede önemli bir figür hâline gelmiştir. Belki de tam da bu odakta konumu nedeniyle yöneltilen eleştiriler de çoğunlukla Schechner'i ve fikirlerini hedef almıştır.

Temelde eleștirilerin iki ana damarda ilerlediğini gözlemlemek mümkündür. Bunların ilki 1980 sonrası toplumsal yapının tüm katmanlarını saran ve temelde Batı merkezli bir fikir olarak performansın yeni bir kurallar ağı yaratmasını tartışmaya açmakta iken, diğer damar performansın tiyatroyu kapsama biçimine odaklanır ve bu özelliği ile de kaçındığı bir sınır çizme fikrine kendisinin dayandı̆̆ını iddia eder.

Eleştirilerin birincil damarında John McKenzie'nin tespitleri önemlidir. Perform or Else: From Discipline to Performance (2001) isimli çalışmasında McKenzie, performansı ve onun eşikselliği merkeze alan yapısını ele alır. 1980 sonrasının temel ideolojisinin modern dönemin disiplin odaklı hâlinden çıkarak performans odaklı bir hâle geldiğini, bu yönüyle de yine Batı düșüncesinin bir sonucu olarak ortaya atılan performansın yeni çağın hâkim paradigması olduğunu ve eşiğe konumlandırılan düşüncenin de bir norm hâlini aldığını söyler. McKenzie iddiasında, performansın kendini konumlandırdığı alan olarak 'liminal'i eski normun yerini alan, yeni kuralları ile bir anlamda kendi içinde paradoksal bir egemen paradigma olarak düşünür. Ve tüm kurallardan ve sınırlamalardan kaçışın, sınırları ihlal etme ya da ona direnmenin kendisinin bir kurala dönüştüğ̈nü ve yeni sınırlar belirlediğini iddia eder. Buna da liminal-norm adını verir (McKenzie, 2001, s. 52).

Yeni bir paradigma olarak performans ve liminal-norm aynı zamanda Batı'nın sahip olduğu ekonomik, kültürel ve hatta akademik gücün, alanın tamamını yönetmeye başlaması riskini taşımaktadır. McKenzie bu düşünceyi merkeze alarak başka bir yerde (2006, s. 5-8) performans araştırmalarının örtük bir emperyalist yan taşıyabilme riskine dikkat çeker. Bu tartışma oldukça genişlemiş, Schechner ve çeşitli isimlerin yanıtları ile sürmüștür. Yeni paradigmanın aynı zamanda değișen toplumsal yapının bir dillendiricisi olma ya da 1980 sonrası kültürel hegemonyanın merkezi olarak görülen Amerika merkezli bu fikrin, 'öteki' üzerinde tahakküm kurma ihtimaline dikkat çekilmiştir. Kuşkusuz bu tip bir eleștiri Schechner'in niyeti üzerinden yürütülmemektedir. Burada hedef alınan - belki biraz da içselleştirilmiş bir hâlde - düşüncelere ve eylemlere sirayet edebilen egemen düşüncenin kuşatıcı etkisidir. McKenzie kişilerin ya da çalışmaların emperyalist olduklarını söylememekte ama farkında olmadan emperyalistlerin dilinden konuşur hâle gelip gelmediklerinin yani kendileri üzerindeki emperyalist etkinin düşünülmesi gerektiğinin $(2006$, s. 7) altını çizmektedir. Bu tartışma performans çalışmalarının İngilizce merkezli oluşunun ve hatta yürütülen 
uluslararası konferanslarda İngilizce'nin hâkimiyetinin yaratabileceği handikapları dikkate almak gerektiği noktasına kadar taşınmıștır ${ }^{1}$.

Eleştiriler için ikinci bir boyut bu ilk damarla bağlantılı olduğu gözlerden kaçmayan bir tiyatro savunusu merkezlidir. Bu eleștirilere örnek Beliz Güçbilmez ve Marvin Carlson'un ifadeleri özelinden verilebilir. Tiyatronun bakıș açısından Schechner'in kurduğu dizgenin ve kapsayıcı performans düșüncesinin soğurucu ve pasifize edici bir sınırlandırmaya dayandığını ve alanların dinamik ve çeșitli tarihsel, toplumsal, kültürel süreçlerinin yok sayıldığını ifade eden eleştiriler şöyle özetlenebilir: Beliz Güçbilmez, Tiyatro/Metin/Performans isimli makalesinde performansta neredeyse tiyatrofobiye varan bir yan olduğunu söyler. Alanın dinamik ögeleri yok sayılmış, geriye neredeyse tarifi, sınırı belirli bir tiyatro düşüncesi bırakılmıș ve bu da performansın kapsamına alınmıștır. Güçbilmez'e göre bu kapsama hâli sınırlardan kaçarken sınırlar çizen bir düșünce yarattı̆ı gibi diyalektik bir tiyatro-performans okumasının da yolunu tıkamaktadır (2012, s. 367-369). Carlson ise tümden bir performans eleştirisine girişmese de tiyatral performansın "(...) kültürel ve toplumsal üstyorum yapmak, kendi ile ötekinin, deneyimlediği biçimiyle dünyanın ve alternatif imkânların keșfedilmesi” (2013, s. 286) konusunda taşıyabileceği sorumluluğun tümden bir performans düşüncesi tarafından yutulmaya direnebileceğini söyleyerek bir tiyatro savunusu yapmıştır.

$\mathrm{Bu}$ noktada iki eleştirel damarın da aslında performans düşüncesinin kaçındığı kimi tuzaklara yakalanabilme riski taşıdığını ifade ettiği görülür. Çalışma içerisinden bu eleştirel dizgeye bir katkı sunmak gerekirse, isim değiștirmesinde görülen tutumu, 'öteki' kültürün örneklerine ulașabilmek için kendisini ironik bir şekilde - konumlandırdığı bir başka aradalık hâli gibi görünse de diğer yandan farklı olana ulaşmak için izlenen ve soğurucu bir strateji olarak da okunabilmektedir. Böyle bir bakışla 'öteki kültürden materyal taşımama' amacından belirli bir sapmayı ifade etmekte ve kendi teoremini besleyecek kaynaklara ulașmak için verdiği çabadan anlașllacağı üzere 'öteki'ne kendi teoremini beslemek için de erișmektedir. Kuşkusuz bir çeşit etkileşimin tam olarak önünün kesilemeyeceğini kendisi de dillendirmiștir; dahası bunun mümkünlüğü de oldukça tartışmalıdır. Ama kendini diğer araștırmacılar karşısında konumlandırırken ifade ettiği fikirlerden bir anlamda kendisinin ve teoreminin de kaçınmasının mümkün olmadığını söylenebilir.

\section{Sonuç}

Richard Schechner'in 1960'larda başlayan toplumsal krizlere ve bunun kültürel-sanatsal ortama yansımalarına, oluşan düşünsel çıkmazlar ve sanat-hayat korelasyonuna çözüm üretmek için performans başlığında yeni bir paradigma yarattığı görülmüştür. Bu paradigma, Arnold van Gennep ve Victor Turner gibi antropologların araștırmaları ile teorize edilen 'eșik' kavramını sadece kuramsal bir saptama olarak ödünç almamış aynı zamanda düșünsel izleğinin odak noktası hâline getirmiştir. Schechner çalıșma içerisinde de yoğun olarak ifade edildiği gibi 'eşikselliğe', 'aradalık'lara değer verirken ısrarlı bir tutumla Batılı aklın dizgesinin kırılması, sınırlama ve sınıflama ağlarının dışına çıkılması gerektiğini belirtir.

Genel olarak bakıldığında Schechner'in kapsayıcı yaklaşımların, köken arayışlarının uzağında durduğu oldukça nettir. Farklı kültürlerin ve toplumların ilişki biçimlerini, anlayışlarını ve tarihsel süreçte inşa ettikleri yapılanmaları 'performans'ın bakış açısından görmeye çalışır. Politik bir duruşla, egemen kültürlerin, satış odaklı yaklaşımların hegemonyasının dışında bir anlayış inşa etmek ister. Kültürlerin, izole edilmiş yapılar değil etkileşimli yapılar olmasını önemserken, güç ve iktidar ilişkilerinin manipüle edici ya da ötekileștirici anlayıșından korunmak gerektiğini vurgular.

Doğa ve kültürün, hayat ve sanatın bir karșıtllk olarak örgütlendiği düșünce sistemlerinin karșısına bir alternatif olarak çıkarılan performans paradigması, eșikselliğin dönüştürücü yanını vurgulamakta ve benöteki ayrımının tahakküme dayanan yapısına karşı, 'ben'deki 'öteki'yi ve 'öteki'deki 'ben'i görmeyi amaçlamaktadır. Performans çalıșmaları aynı zamanda bireysel edimleri, tarih dıșı ya da özerk gibi görünen davranış ya da düşünceleri sosyal bağlamda görmeyi kolaylaștırmakta ve refleksif bir praksisin ortaya çıkmasını sağlayabilme gücü taşımaktadır.

Ama tüm bu bahsi geçen potansiyel, eleştirilerden de yola çıkarak söylemek gerekirse diyalektik bir düșüncenin daimî kılınması ile mümkündür. Performans düşüncesinin kimi anlarda kaçındığı tuzaklara kendisinin düșme ihtimali olduğu netlikle görülmüștür. Sonuç olarak 1980 sonrasının kültürel yöneliminin başat unsuru olarak performans, içine doğduğu (ya da onu doğuran) toplumsal yapı ile bir arada ele alınmazsa ve bu sürecin getirilerinin bir ürünü olması noktasında kendine dönük eleștirel bir süreci daimî

\footnotetext{
1 Burada bahsi geçen tartışmalar ve yanıtların detaylarına The Tulana Drama Review dergisinin ilgili sayılarından ulaşılabilir (Bkz. McKenzie, 2006; Reinelt, 2007; Schechner, Barba, Tomoko ve Yuichiro, 2007).
} 
kılamazsa, sınırları imha etmeye çalıştığı her keskin savunuda yine kendi silahı ile vurulur bir hâle gelme riski taşımaktadır. Schechner'in performans düşüncesinde, türleri tanımlarken kurduğu hiyerarşik dizgeyi kendisini önceleyerek yapması, McKenzie tarafından da dikkat çekilmiş olan emperyalist olma riskinin nasıl da- niyetler nasıl olursa olsun- aradalıklardan sızabildiğinin bir göstergesi olarak okunabilmektedir. Ya da bu fikir, tüm tanımlamalarını diğerine geçişin mümkünlüğü üzerinden kurguladığında her bir kavramı diğerinin içinde eriten bir postmodern bakışa göz kırpma riski taşıdığı görmezden gelinmemelidir.

\section{Kaynakça}

Auslander, P. (2002). From acting to performance. New York: Routledge.

Bial, H. (2011). Today I am a field: Performance studies comes of age. In J. M. Harding and C. Rosenthal (Ed.), The Rise of Performance Studies (pp. 85-97). New York: Palgrave Macmillan.

Carlson, M. (2007). Tiyatro teorileri. (E. Buğlalılar ve B. Yıldırım, Çev.). Ankara: deki Yayınevi.

Carlson, M. (2011). Performance studies and the enhancement of theatre studies. In J. M. Harding and C. Rosenthal (Ed.), The rise of performance studies (pp. 13-22). New York: Palgrave Macmillan.

Carlson, M. (2013). Performans: Eleştirel bir giriş. (B. Güçbilmez, Çev.). Ankara: Dost Kitabevi.

Cutungo, C. (2013). Richard Schechner's performance studies. Interwiev with Richard Schechner. Mantichora, Rivista annuale peer-reviewed- n. 3 Dicembre, 135-147.

Dalyanoğlu, D. (2010). Tiyatro, kültürlerarasıcıllk, sosyal avangard: Richard Schechner ile söyleşi. Mimesis Dergisi, 17. 27-45.

Epskamp, K. (2003). Intercultural puzzles. Richard Schechner and the anthropology of theatre in the 20th century. Anthropos, Bd. 98, H. 2 (pp. 499-509).

Goffman, E. (2009). Günlük yaşamda benliğin sunumu. (B. Cezar, Çev.). İstanbul: Metis Yayınları.

Güçbilmez, B. (2012). Tiyatro/metin/performans. Ö. Belkıs. (Ed.), Prof. Dr. Özdemir Nutku'ya Armağan Kitabı içinde (s. 353-371). İzmir: DEU Yayınları.

Harding, J. M. ve Rosenthal, C. (2011). Introduction: The rise of performance studies. In J. M. Harding and C. Rosenthal (Ed.), The Rise of Performance Studies (pp. 1-10). New York: Palgrave Macmillan.

Huizinga, J. (2013). Homo ludens. (M. A. Kılıçbay, Çev.). İstanbul: Ayrıntı Yayınları.

McKenzie, J. (2001). Perform or else: From discipline to performance. New York: Routledge.

McKenzie, J. (2006). Is performance studies imperialist? The Tulane Drama Review, 50(4). 5-8.

Reinelt, J. (2007). Is performance studies imperialist? Part 2. The Tulane Drama Review, 51(3). 7-16.

Schechner, R. (1966). Approaches to theory/criticism. The Tulane Drama Review, 10(4). 20-53.

Schechner, R. (1977). Essays on performance theory 1970-1976. New York: Drama Book Publishers.

Schechner, R. (1985). Between theatre and anthropology. Pennsylvania: University of Pennsylvania Press.

Schechner, R. (1989). Intercultural themes, Performing Arts Journal, 11(3)- 12(1), The Interculturalism Issue. 151-162.

Schechner, R. (2003). Performance theory. New York: Routledge.

Schechner, R., Barba, E., Tomoko, K. ve Yuichiro, T. (2007). Is performance studies imperialist? Part 3. The Tulane Drama Review, 51(4). 8-16.

Schechner, R. (2010). Performans çalışmaları: Geniş yelpaze yaklaşımı. (Ö. Ongun, Çev.). Mimesis Dergisi, 17. 47-50.

Schechner, R. (2013). Performance studies: An introduction. New York: Routledge.

Schechner, R. (2015). Ritüelin geleceği. (Z. Ertan, Çev.). Ankara: Dost Kitabevi.

Turner, V. (2018). Ritüeller, yapı ve anti-yapı. (N. Küçük, Çev.). İstanbul: İthaki Yayınları. 